\title{
Two approaches to scientific aid for disaster areas
}

\begin{abstract}
Scientists and nonscientists alike are becoming increasingly aware of the need for science to be 'relevant'. In human terms, perhaps the most im. portant applications of science are to the problems facing the less developed parts of the world, and the need for relevant science can be seen most clearly at times of crisis-such as the recent floods in Bangladesh. But how effectively is science being used in such situations? John Gribbin and John Wilson have been looking at two contrasting approaches to these problems.
\end{abstract}

ESTABLISHED charitable organisations such as Oxfam are making increasing use of science and technology in their work; it is becoming accepted that provision of food to survivors of a disaster is no more than a temporary solution to any problem, and that famine and disease can only be prevented by more fundamental help. But still, only a tiny fraction of Oxfam's income, for example, is spent on research - although that small budget seems to be used remarkably effectively.

Among projects Oxfam is working on are:

- A completely new sewage disposal system which can be flown straight to disaster areas and is, according to Oxfam, cheap, simple and easy to erect.

- A new building technique to provide rapid emergency housing after an earthquake, flood or other catastrophe.

- An investigation of bicycle 'pedal power' in the poorer countries.

These are all projects with a sound scientific pedigree. The sewage scheme, for example, required fundamental research on the biology of the cholera vibrio. But money allocated by Oxfam to such research was only $£ 3,000$ in 1973, out of a total 'income' from public donations of $£ 4.2$ million, more than $80 \%$ of which was spent overseas.

The Deputy Director of Oxfam, Mr Guy Stringer, explains that the best use is made of this $£ 3,000$ by using Oxfam money only to prime the financial pump of a project. Once a plan has shown potential, Oxfam seeks help from other sources. This falls into.line with the organisation's avowed policy of spending as much of the public's money as possible 'over there' rather than on research at home. And the people and firms that Oxfam approaches are eager to help. "They have never refused us", says Mr Stringer.

Oxfam undoubtedly benefits enormously from this goodwill; but part of its success must surely lie in the simple direct approach which it adopts. The charity first became interested in sanitation schemes as a result of its experience of the refugee camps in Bengal during the Indo-Pakistan conflict of 1971. Oxfam workers there realised that most of the relief effort was being spent on the treatment of diseases arising from the insanitary conditions within the camps. Even so, this preventive medicine was often ineffective-particularly against cholera.

At first Oxfam simply tried to contain the excrement and other wastes of the refugees. It found that one possible container (a 30,000 gallon collapsible fuel tank belonging to the RAF) provided almost instant anaerobic conditions. From that discovery sprang the idea of destroying the cholera and dysentery bacteria anaerobically.

As no one knew the viability of Vibrio cholerae in anaerobic sewage, Oxfam asked Mr Barry Lloyd of the University of Surrey to find out. To keep costs as low as possible, Mr Lloyd presented the project to two final year students as the topic for their degree theses. Although each thesis 'cost' about $£ 800$, Oxfam paid only a tenth of this for the results.

The survival of the vibrios was found to depend on the temperature of the sludge and the proportions of solid matter in it. Vibrios were usually eliminated after 7 days at $37^{\circ} \mathrm{C}$ but at $25^{\circ} \mathrm{C}$ took 12 days to disappear. Once Oxfam had an estimate of how long the sewage should be retained in anaerobic conditions, it was able to seek the advice of the Water Pollution Research Laboratory at Stevenage, and the University of Loughborough on the general layout and hydraulics of the unit. The Plastics Research Group at the Atomic Energy Research Establishment, Harwell, designed a mould for a cheap stackable plastic squatting unit-the Asian equivalent of a toilet seat.

Mr Jim Howard, Oxfam's Industries Officer, emphasises the importance of this squatting unit. Produced now for a matter of shillings, they replace heavy vitreous china items that cost about $£ 50$.

The sanitation package on which Oxfam has now decided consists of two or three large butyl rubber tanks holding some 4,500 gallons each, connected in series to a group of 20 squatting units. During October, a team from Oxfam will be taking an example of each unit to Bangladesh. With the cooperation of the Cholera Research Laboratories in Dacca, the two-bag unit will be tested on hospital effluent known to be rich in cholera bacteria and the three-bag system will be set up in a Bihari refugee camp to assess its impact on an existing community.

Even including the cost of this visit, Oxfam says it has spent less than $£ 1,500$ on the entire sewage project. Once the scheme was underway the Leverhulme Trust provided a grant of $£ 19,000$ and the British Government gave $£ 6,500$. The charity holds British, United States and Canadian patents on the system so it may still recoup what little it spent. With the addition of antifreeze the technique might be adapted for use in the Arctic or Antarctic.

The sanitation scheme is probably the most ambitious technical project that Oxfam have tackled and it typifies the organisation's direct approach to disaster relief. In the same vein, Oxfam is pioneering a building technique which it hopes will provide warm weatherproof shelters quickly and cheaply. Polyurethane foam is sprayed on to the inside of a lightweight aluminium mould. When the foam hardens, the mould is removed leaving a house with approximately 70 square feet of living space.

The mobile factory to spray the foam costs about $£ 4,500$ and Oxfam claims that the chemicals needed for one house may be bought for $£ 30$. Polystyrene granules are cheaper-and are rather more fire resistant- - but the apparatus needed to steam them into place is six or seven times as expensive as the polyurethane apparatus. In September, Oxfam will be training two volunteer teams in the spray building technique.

In many underdeveloped countries a great propontion of the labour forceas much as $15 \%$ in some cases according to $\mathrm{Mr}$ Howard-spends its time moving water for irrigation. Oxfam is now trying to develop a portable 
Native huts, Oxfam style. An aluminium shell is lowered into place (left) and removed after serving as a mould (right).

water pump that could be powered by pedals in the same way as a bicycle. It is also investigating this use of pedal power to drive simple winnowing or grinding machines. With $\mathrm{Mr}$ Stuart Wilson, of the University of Oxford, it is developing a superior rickshaw, and a four wheel drive pedal platform or 'Pedalrover' which could carry half a ton across country; Zambia has already expressed an interest in this idea.

Oxfam does not always design its schemes for its own use. In 1971 it began a project to turn Britain's surplus potato crop and skimmed milk into a balanced emergency diet. Although Oxfam persuaded Cadbury Schweppes to let it use their powdered potato production lines at cost price it still spent $£ 6,250$ of its own money. Mr Howard feels that since Oxfam's new food is now accepted by the World Food Programme, it is up to the govennment to use the recipe when and if a surplus occurs again.

But Oxfam is not without its critics. Some people have expressed concern, for example, that any temporary housing provided after a disaster might remain occupied when conditions returned to normal, degenerating into instant slums. Oxfam admits that further work is needed to determine an optimum spacing of such units to minimise the fire hazard while housing as many people as possible-but it is fundamental to their philosophy that such housing is needed, although a case can be made that in many places, such as Bangladesh, the local population already possesses both the skills and the material needed for the rapid erection of cheap lightweight shelters.

At a more fundamental level, questions might be asked about whether such organisations as Oxfam are in fact the best bodies to organise scientific aid for disaster situations. The point is debatable; but it is true that Oxfam is not run by scientists, and that its scientific activities are still very much an appendage to the main work. So it is interesting that a group of Londonbased scientists is trying just the opposite approach. The London Technical Group (LTG) is a group of scientists from various disciplines which is looking at problems of disaster relief solely from the scientific and technological point of view.

The most widely available tangible product from the group so far is an

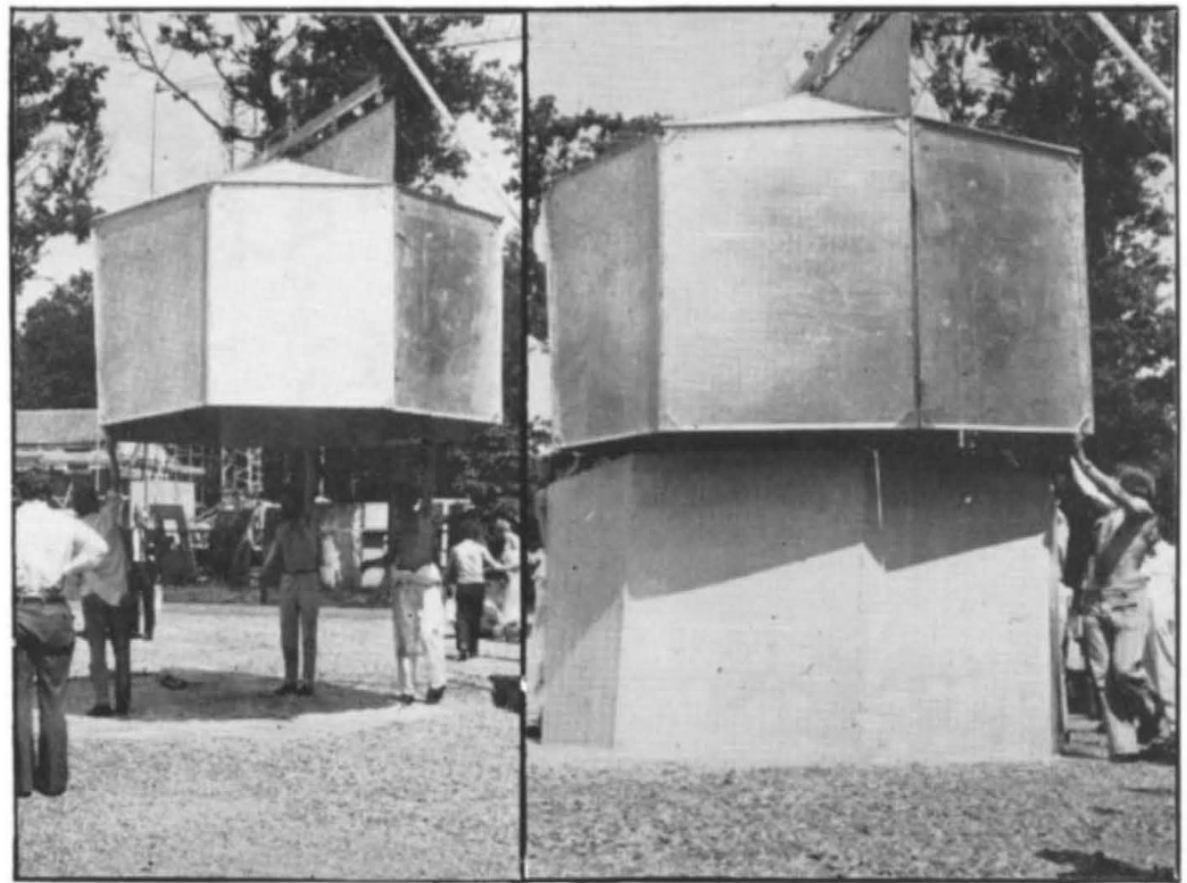

annotated bibliography of papers relating to Disaster Technology (LTG, 55 Evelyn Gardens, London; 1974). This typifies one aspect of the group's activities to act as a clearing house for relevant information and, hopefully, to ensure that such information does not disappear from the general awareness. Members of the group say that they have been astonished at how often 'new' ideas turn out to have been presaged years or even decades ago. They cite the example of the compression effects which cause internal injuries in victims pulled from collapsed buildings and have been "discovered" after almost every major earthquake affecting built up areas. In fact, they say, these problems were thoroughly investigated more than three decades ago, when many people were trapped in collapsing buildings during the mass bombing of the Second World War.

But the LTG is not just concerned with collecting and distributing information. Members of the group (now some 30 strong) see the LTG as something of a centre of expertise in terms of field experience of disaster and famine situations, eager to hire out their skills to anyone who can use them.

The oppontunity for scientists with such expertise to meat regularly and discuss problems provides the third string to LTG's bow, as a 'disaster think tank'. Such ideas as mixing dried skim milk with oil to form a drinkable and nutritious emulsion (with the addition of appropriate substances to make it palatable) and an emphasis on rugged simplicity for all field equipment emerge from these meetings. Individual field trips made by members of the LTG have provided the essential training in basics which encourages the group to think that it now has the experience to, say, carry out surveys of nutritional problems on behalf of governments or other bodies, who would put up the money and collect the results on a contractual basis. These trips also, of course, provide valuable information in their own right. Mr John Rivers, a member of the LTG, has just returned from Ethiopia, where he carried out a nutritional survey with Dr John Seamen as part of a UNICEF project, partially funded (to the tune of $£ 1,000$ ) by Oxfam. It seems from this work that the general feeling that protein deficiency may not be the greatest nutritional problem in famine areas may well be correct; the normal food of the nomads in Ethiopia includes milk, cereal and a little meat. In the present famine situation they are forced to eat other foods, such as beans. But there is no evidence that the quality of these foods is inadequate, whatever the problems of finding enough food; and this means that any emphasis on protein supplements as a high priority in famine relief is wrong, at least in this case.

It remains to be seen whether any charity or other organisation will jump at the oppontunity of hiring the LTG team of scientific specialists as a group to do this kind of work, or whether the LTG will continue simply as a collection of concerned scientists devoting their spare time to efforts aimed at improving the way science is used to combat disasters. The approach they advocate is, however, worthy of serious consideration if only as a reminder that there are alternatives to the existing systems which have, by the nature of things, become 'the establishment'. 